\title{
POCHWAŁA SAMOUCTWA W KONTEKŚCIE ROZWAŻAŃ NAD OSOBNOŚCIĄ I SAMOTNOŚCIĄ - NA TLE KONCEPCJI SAMOKSZTAŁCENIOWEJ WŁADYSŁAWA M. KOZŁOWSKIEGO**
}

Streszczenie: Autorka rozważa dzisiejszy sens i znaczenie samouctwa w powiązaniu z osobnością i samotnością - na tle jednej z historycznych koncepcji samokształceniowych w Polsce. Osobność jako sposób istnienia człowieka, istoty myślącej, jest filozoficznym punktem wyjścia dla analizy. Zakłada się, że edukacja ma do spełnienia ważną rolę w uczeniu myślenia, które jednak wymaga bycia osobno, ze sobą samym (u siebie). W związku z czym autorka proponuje przywołać jedną z koncepcji samouctwa, rozwijaną w czasach zaborów i w okresie międzywojnia w Polsce, jako przykład doświadczania siebie i uczenia się (szkoły) myślenia w samotności, nie poza edukacją ale w jej ramach. Analiza i interpretacja hermeneutyczna zagadnienia pozwala wykazać aktualność samouctwa jako potrzebnego humanizującego dopełnienia współczesnej szkoły w Polsce, balansującej między skrajnościami encyklopedyzmu i instrumentalizmu. A tym samym pozwala zebrać wiązkę argumentów na rzecz wykształcenia niesprowadzalnego do uzawodowienia a sprzyjającego kondycji ludzkiej jako vita activa.

Słowa kluczowe: samouctwo, osobność, samotność, myślenie, wykształcenie samego siebie, wychowanie i kształcenie.

* Dr hab. Katarzyna Wrońska, prof. ucz., Uniwersytet Jagielloński, Wydział Filozoficzny, Instytut Pedagogiki; e-mail: katarzyna.wronska@uj.edu.pl.

** Zmieniona wersja tekstu opublikowanego przez autorkę w języku angielskim pt. The Praise of Self-nstruction in the 21st Century - against a Background of Selected Concepts of Self-Education in Poland during the Partitions and Interwar Period. „Paedagogia Christiana” 2020, nr 1 (45), s. $65-82$. 


\section{Wprowadzenie}

Samouctwo postrzega się głównie jako lekarstwo na brak i reglamentację edukacji. W poniższym opracowaniu będę chciała poddać sprawdzeniu, na ile jego wartość sprawdza się także w dzisiejszych warunkach w Polsce. Dzisiejszy kryzys edukacji będę opisywać jako stan, w którym bardziej niż brak (choć i z nim mamy do czynienia, szczególnie na skutek epidemii) zagraża nam upolitycznienie (upartyjnienie i zideologizowanie) oraz instrumentalizacja edukacji. Jak się ów kryzys objawia? Po pierwsze, $\mathrm{w}$ formie konserwowania encyklopedyzmu, po drugie - $\mathrm{w}$ formie redukcjonizmu i instrumentalizowania nauki szkolnej zarówno przez władzę, jak i jej odbiorców. Encyklopedyzm dziedziczymy po czasach gimnazjów klasycznych głównie w modelu pruskim (Alves 2019). Był on rozpowszechniany w samych Prusach i na ziemiach polskich pod zaborem pruskim (wedle formuły: dużo wiedzy pamięciowej i dyscypliny, w klimacie hierarchii szkolnej i zależności od władzy i autorytetu nauczyciela - profesora oraz dyrektora gimnazjum). W czasach PRL encyklopedyzm był normą w liceach ogólnokształcących w krajach komunistycznych. A dziś nauczanie szkolne znów staje się orężem w rękach władzy, chcącej osiągać swoje cele za sprawą wychowania młodego pokolenia. Podmioty edukacji z kolei coraz silniej kojarzą edukację jako środek w pokonywaniu szczebli kariery - w ten sposób edukacja objawia ona swoje drugie extremum - redukcjonizm i instrumentalizm, nie tracąc nic z pierwszego, czyli z obciążenia encyklopedyzmem. Czy taki stan edukacji może sprzyjać myśleniu? Zakładam, że go utrudnia. I przesuwa zetknięcie się i ćwiczenie myślenia na późniejszy etap życia, dla szkolnego rezerwując ewentualne zadomowienie się z myśleniem szkolnym (Kołłątaj 1953).

Myślenie w ogóle nie jest powszechną praktyką, a edukacja w kryzysie może nie pomagać wzbudzać potrzeby myślenia. $Z$ pewnością pobudza ona aktywność podmiotu (w tym kognitywną), ale niekoniecznie opartą na myśleniu (Arendt 2016). Czy więc sprzyja rozwijaniu i nabywaniu zdolności umysłowych (kompetencji otwartego, krytycznego umysłu) oraz osobowościowych (postaw samodzielności, odpowiedzialności)? Można w to wątpić. Co z kolei sprzyja myśleniu?

W swoim tekście będę argumentować, że kapitalne warunki stwarza myśleniu samotność. Nie jest to teza powszechna. A nawet wszystko dziś zdaje się tej tezie przeczyć. Nasza dzisiejsza obecność w kulturze w dużej mierze realizuje się za pośrednictwem nowoczesnych technologii informatycznych - typu smartfon, tablet. To one dziś są oknem na świat, poprzez te narzędzia kontaktujemy się z innymi, nie tylko z bliskimi, dają nam one poczucie, że jesteśmy w stałej - potencjalnej łączności z ludźmi z całego świata i na bieżąco ze wszystkim, co się dzieje wokół nas i w świecie. Widok osób wpatrzonych w ekran swojego smartfona, odczytujących coś z ekranu, wymieniających SMS-owe wiadomości czy prowadzących z kimś rozmowę, to stałe obrazki tworzące koloryt naszych miast i naszej codzienności w przestrzeni publicznej i nie tylko. Tylko czy to jest właśnie owo spotkanie i rozmowa - tylko w nowoczesnym wydaniu? Wątpię. I czy my sami jesteśmy wtedy 
dostępni dla siebie? Czy nie omijamy samych siebie? Wpatrzenie w smartfony może zasadnie opisywać i wyjaśniać nie tyle otwarcie na świat i innych, ile naszą samotność (loneliness) oraz obawę i ucieczkę przed zaglądnięciem do wnętrza siebie, do ja wewnętrznego, przed zatrzymaniem się, aby coś przemyśleć, nad czymś się zastanowić. Może też zwyczajnie opisywać nasze nieprzygotowanie na spotkanie z własną myślą. Tak podchodzi do sprawy np. kanadyjski pisarz Patrick deWitt, opisujący w wywiadzie, jak smartfony odebrały nam samotność (solitude) (deWitt 2019). Traktuję go jako sprzymierzeńca stawianej tu tezy o ludzkiej potrzebie samotności, a dziś zagrożonej, niedocenianej, zniekształcanej do postaci osamotnienia (izolacji, odrzucenia), bądź wymuszanej (tak jak obecnie - z powodu epidemii) i zapoznawanej. A jeśli jesteśmy tak uzależnieni od smartfonów i tak rzadko mamy szansę doświadczać samych siebie (swoją osobność) ${ }^{1}$, to może zadaniem edukacji powinno być uczenie radzenia sobie i obywania się bez urządzeń mobilnych oraz ćwiczenie w byciu ze sobą samym?

Osobność (inaczej bycie osobno, bycie u siebie, ze sobą) jako sposób istnienia człowieka - osoby, istoty myślącej, jest dla mnie filozoficznym punktem wyjścia w rozważaniach o edukacji człowieka oraz nad rolą samotności, w uczeniu myślenia wymagającego bycia ze sobą samym (u siebie). Nie chcę jednak widzieć samotności jako celu samego w sobie, nie o nią samą bowiem tu chodzi. Rzecz w tym, aby uchwycić jej pozytywne oblicze, jako sposobu, metody potrzebnej nam ludziom zabieganym, zalęknionym, wykorzenionym, aby móc doświadczyć bycia osobno, bycia u siebie, ze sobą; jako metody na zatrzymanie się, żeby móc doświadczyć myślenia, refleksji o sobie, innych i o świecie. Myślenie z kolei chciałabym widzieć jako cel sam w sobie, walor osoby, stanowiący niejako jej imię, obok jej wolności i otwarcia na dialog i spotkanie $z$ drugim.

$\mathrm{W}$ tym celu proponuję odświeżyć koncepcję samouctwa, traktując ją jako jeden ze sposobów na dzisiejszy kryzys edukacji w kulturze smartfonów. Jako głos za uczeniem się bycia ze sobą, doświadczania osobności jako spotkania ze sobą i z ja myślącym. Jako potrzebne humanizujące dopełnienie szkoły w Polsce, balansującej między skrajnościami encyklopedyzmu i instrumentalizmu. Sięgnę do historycznych tekstów pedagogicznych z czasów braku i reglamentacji w Polsce edukacji publicznej z powodu zaborów, licząc na argumenty odnawiające sens edukacji i użyteczne z dzisiejszej perspektywy. W czasach zaborów samouctwo było hasłem popularnym, postulowanym w gronie polskich intelektualistów zaangażowanych w działalność krzewiącą postawy obywatelskie i patriotyczne w kraju poddanym zaborczej, wynaradawiającej polityce. W międzywojniu w dalszym ciągu koncepcje samouctwa były rozwijane z powodu wad w tworzonym wówczas oficjalnym systemie szkolnictwa. Przywołam z tego grona jedną mniej znaną postać - Władysława M. Kozłowskiego - który żył w latach 1858-1935, a więc zdołał

1 Z pewnością nie chciałabym kojarzyć osobności z dzisiejszym przymusowym - wywołanym pandemią - sztucznym byciem w izolacji i zachowywaniem między ludźmi dystansu przestrzennego. 
doświadczyć niewoli, łącznie ze zsyłką na Syberię, a następnie odbudowywania państwowości i systemu powszechnej oświaty. Sam Kozłowski oceniał swoją pracę na rzecz (samo)kształcenia się rodaków jako spełnianie obowiązku obywatelskiego i działanie na rzecz wolnej i demokratycznej Polski, która wymaga od swoich obywateli rozumu i samodzielności.

Zakładam, że w wyniku przeprowadzonej analizy samouctwa uda się wykazać pożyteczność samotności w życiu człowieka, a wraz z nią możliwość uczenia się i doświadczania osobności jako sposobu bycia ze sobą samym i jako szkoły myślenia w samotności. W podsumowaniu chciałabym zaprezentować wiązkę argumentów na rzecz wykształcenia niesprowadzalnego do uzawodowienia, a sprzyjającego kondycji ludzkiej jako vita activa - wydobytą z koncepcji samouctwa.

\section{Osobność jako doświadczanie siebie i szkoła myślenia w samotności}

Bycie u siebie, osobno, jako sposób istnienia człowieka (bytu osobowego, bycia osobą, istotą myślącą), traktuję jako filozoficzny punkt wyjścia w rozważaniach nad edukacją i jej rolą w uczeniu myślenia. Myślenie bowiem wymaga od podmiotu - wśród najróżniejszych warunków - bycia ze sobą samym (u siebie). To bycie osobą - osobno - ma różne odsłony. Startując od samego początku, małe dziecko nie ma jeszcze wykształconej zdolności ujmowania siebie jako odrębnego ja, wypowiada się o sobie w trzeciej osobie, postrzega siebie w sposób nieodróżnialny od otoczenia, boi się oddalenia od siebie matki. Z drugiej strony stawia się jako wartość docelową ludzkiego rozwoju - autonomię. Między jednym a drugim sytuuje się całe spektrum form pośrednich, przez które przechodzi się w drodze od dzieciństwa do dorosłości, od zdania się na innych i zależności do autonomii. Ten czas wypełnia edukacja. W tej przestrzeni powinno się więc zatroszczyć o wymiar bycia ze sobą osoby uczącej się.

Genetycznie tym, co poprzedza myślenie, uruchamiane przez pojedynczy podmiot, jest spotkanie, doświadczenie bliskości osoby, która jest gotowa przyjąć na siebie powiernictwo nadziei dziecka. Tu mieszczą się wskazania filozofa dialogu Józefa Tischnera o spotkaniu i rozmowie jako początku myślenia, w odniesieniu do sceny pedagogicznej. „Nic tak nie daje do myślenia jak drugi”, mówił w rozmowie z Anną Karoń-Ostrowską (Tischner 2008, s. 130). Dialog był dla niego początkiem wszelkiego doświadczenia świata, również doświadczenia Boga. W każdej jego postaci człowiek jest zaproszony do myślenia, w tym etycznego (aby stawać w prawdzie wobec bliźniego, nie okłamywać go, być mu wiernym, być powiernikiem czyjejś nadziei) i religijnego (łącznie z dotknięciem granic myśli). W następnej kolejności, a więc o krok dalej, potrzebne już będzie stałe równoważenie (łagodzenie) relacji podległości i zależności od wychowawcy/nauczyciela/rówieśnika doświadczeniem autoedukacyjnym i możliwościami, jakie daje problem do samodzielnego rozwiązania, który stawia sam uczący się przed sobą lub nauczyciel/wychowawca, któremu uczący się zawierza (a nie tylko wykonuje przydzielone mu zadanie) (Wrońska 
2018). Pamiętamy, jak u Johna Stuarta Milla totalna relacja z ojcem wymagała najpierw zerwania pedagogicznej z nim relacji, aby edukacja nabrała charakteru samodzielnej pracy kształceniowej, w tym doświadczania bycia ze sobą bez uczucia deprywacji (Wrońska 2012).

Warto w tym miejscu przywołać kilka uwag fenomenologa Romana Ingardena o osobie z odniesieniem do osobności. W ujęciu autora Książeczki o człowieku wartość człowieka jako osoby polega na tym, że jest on wykrystalizowany bądź znajduje się w drodze do wykrystalizowania się, że jest scalony. Jego centrum stanowi bytowe, osobowe „ja”, świadomy podmiot. To „ja” jako osoba posiada charakter, jest wolne (świadome swej wolności), a więc ma w sobie centrum działania zdolne do uchwycenia inicjatywy, a z drugiej strony musi być względnie izolowane od otoczenia. Człowiek jest osobą co najmniej in potentia (Ingarden 1989, s. 237). W biegu życia może rozwijać swój potencjał osoby. Wśród wartości osobowych, które warto pielęgnować i doskonalić w swoim życiu, Ingarden wyróżnił: świadomość, wolność, siłę charakteru, inteligencję, szczęście, wszechstronność, głębokość, samodzielność, wewnętrzny krytycyzm, indywidualność. Jest to według niego podstawowe wyposażenie osoby, ale zaniedbane może objawić swój brak lub przeciwieństwo, czyli słabość charakteru, intelektualną tępotę, brak rozumienia czegoś, ubóstwo duchowe, płytkość zainteresowań, uczuć i myśli, niesamodzielność, dogmatyzm i nieodróżnialność (upodabnialność). Obok tych cech wyróżnił jeszcze samą wartość osoby - owo scalenie, wykrystalizowanie. Oznacza to, że choć osoba podlega zmianom czasowo określonym, historycznym, to jest w niej trwały, istotny rdzeń, podstawa i źródło zarówno gatunkowych procesów rozwojowych, jak i indywidualnego sposobu, w jakim dokonuje się rozprawa życiowa między nią a światem. Dopiero na tej bazie zintegrowania psychofizycznego Ingarden kreśli wymiar dignitas osoby (Ingarden 1989, s. 238). Tę szczególną godność nadają osobie czyny moralne. „Jestem siłą, co chce być wolna. Trwać i być wolna może tylko wtedy, jeżeli samą siebie dobrowolnie odda na wytwarzanie dobra, prawdy, piękna. Wówczas dopiero istnieje" (Ingarden 1987, s. 68). Scalenie psychofizyczne poszerza się wówczas o wymiar duchowy, tak iż dochodzi do ujednolicenia wewnętrznego człowieka, jego wewnętrznego uproszczenia. Dzieje się to za sprawą czynu szlachetnego, który uszlachetnia osobę, transformuje ją, rozbudowuje jej zaródź moralną i, co najważniejsze, umożliwia skierowanie się człowieka w swojej podstawowej motywacji - w wyborze opcji fundamentalnej, na pomnażanie dobra, wartości w świecie (Ingarden 1989).

Moralny wymiar bycia człowieka wymaga otwarcia na dialog i zaangażowanie w sprawy innych. Ale przestrzeń i czas dla osobności także powinny być zdefiniowane i zakreślone, aby móc się czuć w tym określonym czasie i przestrzeni u siebie, jako osoba włączona i zdolna do zaangażowania, zdolna do wychodzenia z siebie (z własnej samotni) na spotkanie z innym. Bycie samemu na poziomie umysłowym jako istoty zdolnej do refleksji znajduje dopełnienie na poziomie działania w relacji z drugim człowiekiem i we wspólnocie. Hannah Arendt poświęca temu 
zagadnieniu dużo uwagi. Kondycja ludzka w jej odczytaniu ma dwie twarze; składa się na nią vita activa - aktywność osoby, bycie aktorem wydarzeń i inicjatorem działań i vita contemplativa - ludzka refleksyjność i zdystansowanie. Cenne jest jej rozróżnienie na sferę prywatną i publiczną, gdzie w ramach pierwszej umieszcza się skrytość, intymność, zaś w publicznej - wszystko to, co powinno być z racji swojej rangi wniesione na forum - wypowiadane i realizowane dla i na oczach innych (jako sprawa publiczna) (Arendt 20oo). Osobność dla Arendt to nie tylko wzgląd na intymność i prywatność.

$\mathrm{W}$ związku z podejmowanym w tym miejscu zagadnieniem osobności, jako szkoły bycia i myślenia, trzeba jeszcze przybliżyć inny podział Arendt, pochodzący z pracy Życie umystu, a mianowicie rozróżnienie między intelektem a rozumem (umysłem), z akcentem na przypisaną rozumowi zdolność do myślenia. Jest to szczególnie ważne w związku z edukacją. Intelekt byłby tą aktywnością umysłową, którą najwyraźniej ćwiczy się podczas lat spędzanych w szkołach. Mówimy nawet o wychowaniu intelektualnym, ale rozumiemy przez nie proces kierowany przez nauczyciela. Co innego rozum. Arendt rozpoczyna swoje rozważanie na temat myślenia od przytoczenia starożytnej myśli Katona: „Nigdy [człowiek] nie jest bardziej czynny niż wtedy, gdy nic nie robi, nigdy nie jest mniej sam niż wtedy, gdy jest sam ze sobą" (Arendt 2016, s. 17-18). Dodajmy do tego jeszcze jeden cytat z Katona: „Najwięcej może [człowiek - podkr. K.W.] zdziałać w czasie wolnym od zajęć, a w samotności w ogóle nie czuje się samotny" (Arendt 2016, s. 5). Idąc za tą myślą, Arendt konstatuje, że dziś - bez względu na zasięg współczesnych „śmierci” - Boga, filozofii, metafizyki... - „nasza zdolność do myślenia pozostaje nienaruszona. Jesteśmy tym, czym ludzie zawsze byli - istotami myślącymi” oraz że „ludzie mają skłonność, a może potrzebę myślenia wychodzącego poza granice wiedzy, czynienia więcej tą zdolnością niż tylko używania jej jako narzędzia wiedzy i działania" (Arendt 2016, s. 21). Ta potrzeba będzie, w jej ocenie, wynikiem zachodzącego związku myślenia z dobrem i złem, takiego mianowicie, że „zło może być powodowane przez brak myśli" (Arendt 2016, s. 23). Kryje się za tym problem tzw. banalności zła, w związku z czym Arendt podkreśla, że „musimy żądać jej [czyli zdolności myślenia] od każdego zdrowego na umyśle człowieka, czy jest on erudytą, czy ignorantem, czy jest inteligentny, czy głupi" (Arendt 2016, s. 23). Trzeba więc rozróżniać między dwoma zdolnościami: rozumu (Vernunft) i intelektu (Verstand), czyli dwoma aktywnościami umysłowymi: myśleniem i poznawaniem. Dla Arendt wprowadzone przez Kanta rozróżnienie między wiedzą a wiarą, wyrażone w słowach: „musiałem [...] zawiesić wiedzę, by zrobić miejsce dla wiary”, było niczym innym, jak zrobieniem miejsca dla myślenia (Arendt 2016, s. 24).

Dlaczego myślimy? Po odpowiedź Arendt zwróciła się do Greków, Rzymian, dłużej zatrzymując się przy Sokratesie, nazywając go nauczycielem myślenia. Jej zdaniem uczył on myśleć przyjmując postać gza (żądlił, kąsał pobudzając do myślenia), akuszerki (wydobywał z innych ich myśli) i drętwy (unieruchamiał - dla oka - ale uruchamiał aktywność myślenia) (Arendt 2016). W tym, co robił, był 
niebezpieczny, gdyż zmuszał do myślenia, a ono czyni ludzi nieposłusznymi, niedyspozycyjnymi, nieuległymi wobec władzy. Według Arendt, tym, co u Sokratesa wyzwalało myślenie, była miłość (potrzeba, pragnienie) piękna, sprawiedliwości, mądrości. Trzeba ją więc wzbudzać, bo bez niej jest się niezdolnym do myślenia. Arendt, podobnie jak Sokrates, argumentowała, że zło jest brakiem, ale poszła trochę dalej i skupiła się głównie na braku myślenia (bezmyślności). Byłoby błędem jednak mylić po sokratejsku pojętą miłość (eros) z innymi emocjonalnymi stanami: namiętnością i pewnością przekonania. Te wydają się być w większej mierze barierą dla uruchamiania myślenia. Widać to np. na wiecach polityków, ideologów, kaznodziejów, gromadzących tłumy wyznawców danej ideologii czy światopoglądu, dających gotowe odpowiedzi na różne bolączki i problemy dnia codziennego, i nie tylko. To jest inna droga zaspokajania potrzeb egzystencjalnych, odzyskiwania poczucia bezpieczeństwa i wyzwalania z niepewności i niepokoju, konkurencyjna wobec myślenia. Na te ideologiczne obrazy rzeczywistości jest duże zapotrzebowanie. Czy myślenie w związku z tym mamy widzieć jako przywilej zarezerwowany dla nielicznych? Przeciwnie.

Arendt, dokonując rozróżnienia między poznającym coś intelektem a myślącym o czymś umysłem, broni tezy, że „myślenie w swym niekognitywnym, niespecjalistycznym sensie jako naturalna potrzeba ludzkiego życia, urzeczywistnienie różnicy danej w świadomości, nie jest przywilejem nielicznych, lecz zdolnością stale obecną u każdego; tym samym niezdolność do myślenia nie jest wadą większości, która nie ma wystarczającej sprawności mózgu, lecz możliwością stale obecną u każdego - naukowcy, akademicy i inni specjaliści od przedsięwzięć mentalnych nie są z tego wyłączeni. Każdy może uciec od tego wewnętrznego stosunku z sobą" (Arendt 2016, s. 179-180). Jest to bycie ze sobą samym, ale nie osamotnienie, człowiek bowiem ma sam siebie za towarzysza. Osamotnienie ma miejsce, gdy nie umiemy sobie dotrzymać towarzystwa, „rozdzielić na dwa-w-jednym” (Arendt 2016, s. 174). To „dwa-w-jednym” przyjmuje postać dialogowania ze sobą: jest się i mówiącym, i słuchającym, bezgłośnie. Pozwala to leczyć „samotność myślową" (Arendt 2016, s. 176); umożliwia też zobaczenie człowieka czyniącego zło jako kogoś niezgodnego ze sobą. Mamy z tym do czynienia, według Arendt, w każdej sytuacji, gdy człowiek chce robić z siebie wyjątek i nie stosować się do reguł (ogólnych, dla wszystkich), które chciałby, żeby inni stosowali wobec niego; taka osoba przeczy sobie. „Życie bez myślenia jest możliwe, traci jednak wtedy własną istotę - jest nie tylko bez znaczenia, lecz także nie w pełni żywe. Niemyślący - przekonuje Arendt - są jak lunatycy" (Arendt 2016, s. 180). Można się też zastanawiać, czy faktycznie jesteśmy sami, gdy myślimy. Może wcale nie, ponieważ myśląc możemy przecież prowadzić rozmowę z ludzkością, jak by powiedział Michael Oakeshott. Jesteśmy więc w dobrym towarzystwie, samotność jako deprywacja, czyli osamotnienie, nam nie grozi. A będąc u siebie, można zapraszać do siebie. Goście są mile widziani. Możemy się wsłuchiwać w słowa poetów, w dyskurs naukowców; ich głos przyczynia się do ludzkiej aktywności (Oakeshott 1959, 2001). 
Będąc u siebie, możemy zarazem siebie przekraczać i być dla kogoś drugiego w sposób rozumiejący, akceptujący, pochylając się nad czyjąś biedą czy po prostu chcąc być blisko kogoś lub wysyłając komuś uśmiech. Ale to już dalsza perspektywa, sama Arendt wprowadzi ją w drugim tomie Życia umysłu, poświęconym Woli. Bowiem zwieńczeniem procesu myślenia jako „dwa-w-jednym bezgłośnego dialogu" (Arendt 2016, s. 181) jest u niej władza sądzenia, która urzeczywistnia myślenie w świecie zjawiskowym. Na tym poziomie już nie jesteśmy sami (ze swoim myśleniem), wkraczamy bowiem w świat, w którym wśród innych decydujemy się wydawać sądy o konkretnych rzeczach, faktach i zaangażować się w działaniu. Z kolei Tischner, autor Myślenia według wartości i Etyki solidarności, właśnie w ten sposób upominał się o budzenie do myślenia. To zadanie stawiał przed nauczycielami i wychowawcami (Tischner 2000; 2002).

Dla dzieci oraz dla ludzi zalęknionych, w kryjówkach, schowanych przed światem, jeszcze nieprzebudzonych do myślenia, Tischner - ale także Arendt - dedykują spotkanie (dialog) z drugim. „Zanim zacznę mówić z sobą - opisuje to Arendt rozmawiam najpierw $z$ innymi, sprawdzając, czy rozmowa jest możliwa, i wtedy odkrywam, że mogę prowadzić dialog ze sobą, a nie tylko z innymi. Wspólne jednak jest to, że rozmowę myśli mogą odbyć tylko przyjaciele, a jej podstawowe kryterium, jakby naczelne prawo, głosi: nie przecz sobie" (Arendt 2016, s. 177). U Tischnera pojawi się opis spotkania nie tyle z przyjacielem, co z powiernikiem nadziei; nie może więc zawieść i musi świadczyć słowem, które nie kłamie (Tischner 2000). Arendt i Tischner w tym miejscu się spotykają: dialog nie tylko wypełnia proces myślenia, lecz także pozwala go zainicjować, czyli wprowadzić, zaprosić do myślenia.

Obok argumentów filozofów warto przywołać przemyślenia Patricka deWitta, współczesnego pisarza, który rok temu w wywiadzie udzielonym Natalii Szostak opowiedział o swoich trudnościach w szkole pomimo rozmiłowania w czytaniu i że zdecydował się żyć bez internetu, wychwalając bycie w samotności. Jak przyznał, miłość do książek wzbudził w nim jego ojciec. Wspomniał o nim, że w wieku 17 lat po lekturze $W$ drodze Jacka Kerouaca „postanowił wyruszyć w podróż, na zawsze opuszczając rodzinne strony" (deWitt 2019). W ten sposób sam zrozumiał, że książki mogą mieć wpływ na życie człowieka. Czytanie jednak wcale nie przekładało się na sukcesy szkolne dzisiejszego pisarza. Najwyraźniej czytał nie to, czego wymagał program i nauczyciele. Pisząc własną powieść, zdecydował odłączyć się od internetu, który zabierał mu za dużo czasu. Jak mówił, „smartfony odebrały nam momenty samotności, a ona jest kluczowa dla mojej pracy”. Po napisaniu książki, jak przyznał, jest szczęśliwszy i bardziej produktywny off-line (deWitt 2019).

Jeśli samotność pozwala nam doświadczyć osobności jako sposobu istnienia i przejść przez szkołę myślenia, to przenieśmy ją na grunt edukacji. Czy i gdzie w tej przestrzeni ma ona szansę rezydować? Zakładam, że na poziomie nauki szkolnej trudno będzie ją odszukać. Czy i w jakim stopniu uczeń ma okazję do tego, aby zadać pytanie lub dostać zadanie, żeby konkretny problem przemyśleć lub znaleźć 
sposób na jego rozwiązanie albo uruchomić wyobraźnię i znaleźć samodzielnie problem do zbadania? Czy oprócz poznania i zrozumienia, co miał autor na myśli, ma szansę podzielić się swoimi przemyśleniami po lekturze danego tekstu, czy w ogóle dostaje taką propozycję, aby przygotować swoje pytania do czytanego tekstu, swoje rozwiązania danego problemu, swoją interpretację poznanych faktów, procesów i wydarzeń? Diagnoza wydaje się być bardzo niepomyślna, nie tylko w Polsce (Nussbaum 2016; Postman 1999). A jak było dawniej? Sięgnę więc po spostrzeżenia do polskiej historii, przywołując zapowiadaną w tytule i we wprowadzeniu postać - Władysława Kozłowskiego, żyjącego w obu epokach: polskiej niewoli oraz odbudowy państwowości i systemu powszechnej oświaty. Jego zaangażowanie na rzecz (samo)kształcenia się rodaków w służbie wolnej i demokratycznej Polski spróbuję przenieść na nasz grunt. Tak jak wiek temu, jego postulaty mogą wybrzmiewać z podobną mocą (Brzezińska 1985). Przy zmieniających się warunkach pozostaje bowiem wciąż to samo upominanie się o edukację zaangażowanych i wrażliwych obywateli, osób rozumnych i samodzielnych.

\section{Władysław Kozłowski i krytyka oraz postulaty wobec oświaty - pochwała samouctwa}

Sto lat przed Kozłowskim Hugo Kołłątaj w swojej pracy Stan oświecenia w Polsce w ostatnich latach panowania Augusta III (1750-1764), napisanej już po utracie przez Polskę niepodległości ${ }^{2}$, opisywał kondycję naszego społeczeństwa, w którym dominuje myślenie szkolne, będące zaprzeczeniem dojrzałej jego postaci, opartej na niezależności i samodzielności. Przypomnijmy też jeszcze wcześniejszą postać, Johna Locke’a, który zagadnienia dotyczące ćwiczenia ludzkiego rozumu (właściwego jego używania) opracował oddzielnie, nie włączając ich do swojego podstawowego tekstu o wychowaniu i uczeniu się. W wydaniach pośmiertnych Rozważań dotyczacych rozumu ludzkiego znalazły się one w drugim tomie, jako dodatek do dzieła głównego (Locke 1955). Zatem zdolności umysłu, jako troska podmiotu, omawiane były u niego w dziele adresowanym do dorosłych. Kozłowski był tłumaczem pierwszego tomu Rozważań, i wiemy, że czerpał z tej filozofii (Kozłowski 1921; Wrońska 2015). Można to wyraźnie dostrzec w rozpisanej przez Kozłowskiego i mieszczącej się w ramach ideału wykształcenia samego siebie koncepcji samouctwa ${ }^{3}$. Innym często przywoływanym przez Kozłowskiego autorem był angielski historyk Edward Gibbon. Jego słowa: „Mamy dwojakie wykształcenie - jedne nam dają, drugie zdobywamy sami, a to właśnie jest najcenniejsze” znajdujemy jako motto w poczytnej pracy Kozłowskiego Co i jak czytać? (Kozłowski 1932, s. 1).

2 Dzieło to czekało na pełne, wolne od cenzury, wydanie aż do 2. połowy XX wieku.

3 Szerzej o koncepcji samouctwa w ujęciu Kozłowskiego piszę w odrębnym tekście (Wrońska 2020). 
Jej autor, podobnie jak Locke, głosił pochwałę kierowania się własnym rozumem, w związku z czym zadaniem edukacji powinno być uczenie samodzielnego myślenia. Kształcenie nie jest nauczaniem, tylko wyposażeniem w takie umiejętności i wiedzę, które umożliwią dalsze samodzielne uczenie się, czyli samokształcenie. W sytuacji permanentnego ograniczenia dostępu do wiedzy, w połączeniu z indoktrynacją cechującą oświatę czasów zaborów i pierwszej wojny światowej, Kozłowski znajduje sposób na poprawę kondycji umysłowej swoich rodaków, nie w ramach kształcenia formalnego, ale poza nim, dzięki ich własnej pracy samokształceniowej.

„Zadaniem wykształcenia - pisze Kozłowski - jest wyrobienie ogólnych, ale jasnych i ścisłych pojęć o każdej z nauk, a to w dwojakim celu: 1) jako środka zoryentowania się wśród zjawisk świata i w odpowiednich zjawiskom dziedzinach wiedzy. Człowiek wykształcony powinien posiadać tyle wiadomości z każdej nauki, aby wiedział, dokąd się udać i jak się wziąć do rzeczy, gdy potrzeba lub zamiłowanie każą mu głębiej poznać jakikolwiek przedmiot; 2) jako materiału, z którego wytwarza się pogląd na całość" (Kozłowski 1932, s. 149-150).

Elementarne wiadomości z tych nauk powinny mieścić się w zakresie działania szkoły. Jeśli tak się nie dzieje, pojawia się potrzeba samouctwa metodycznego. Optymalna edukacyjnie jest sytuacja równowagi między samouctwem jako uzupełnieniem nauki szkolnej a wykształceniem samego siebie, czyli trochę nauki szkolnej i trochę samodzielnego kształcenia się. Nierównowaga między nimi rodzi najpospolitszą wadę wykształcenia, objawia się ona oczytaniem w książkach ale nieznajomością podstaw, które powinna dać szkoła (przypadek mędrka, który jest oczytany, przerzuca się z tematu na temat i zmienia poglądy wraz z kolejną przeczytaną lekturą). Jeśli zaś dominuje samouctwo uzupełniające naukę szkolną, a brakuje starań nad wykształceniem samego siebie, mamy wtedy przypadek wiecznego ucznia - encyklopedysty. Kozłowski mówi zdecydowanie, że wykształcenie, choć opiera się na szerokiej wiedzy, w najmniejszym stopniu nie powinno być encyklopedyczne lecz syntetyczne. Jak powie, „nie ilość wiadomości, ale ich spojenie z sobą” stanowi o wartości wykształcenia (Kozłowski 1932, s. 150). Wykształcenie samego siebie wiedzie do emancypacji człowieka. Wymaga to jednak wyrobienia własnych przekonań, te zaś są wynikiem pracy własnej, choć szkoła powinna przygotować do tego grunt przez rozwijanie uczuciowych i intelektualnych podstaw do pracy samodzielnej (Kozłowski 1932; Brzezińska 1985). Gdyby zaś szkoła chciała zastąpić kształcenie i wychowanie samych siebie, „smutny byłby los takiego społeczeństwa”, konstatuje Kozłowski (1932, s. 22).

Wszechstronne wykształcenie samego siebie wytwarza wszechstronny światopogląd jednostki; dokonuje się w nim integracja uczuć, woli, wiedzy i gotowości do czynu. To, co według Kozłowskiego wyróżnia taki światopogląd, to: 1) konsekwencja, czyli staranne usuwanie sprzeczności wewnętrznych w swoim doświadczeniu; 2) naukowość, czyli opieranie swoich wyobrażeń na wiedzy; 3) krytycyzm, czyli poprowadzenie granicy między wiedzą a wiarą i 4. uwolnienie się od ślepego podążania za tradycją a kierowanie się ideałami korzystając $\mathrm{z}$ dorobku genialnych 
twórców przeszłości. I przekonuje, że o ile ma się trochę czasu wolnego od pracy, przy wsparciu instytucji uprzystępniających wiedzę i naukę, a więc w otoczeniu sprzyjającym zakładaniu muzeów, bibliotek, prowadzeniu otwartych wykładów itp., praca nad sobą (wokół wykształcenia samego siebie), może przewyższyć efekt kształcenia formalnego (Kozłowski 1902).

„Samouctwo”, o ile miało oznaczać nie tylko naukę zastępczą wobec szkoły, ale też uzupełnienie nauki szkolnej, możemy, jak sądzę, próbować zastąpić słowem „samokształcenie”. Kozłowski starał się przekonywać do samouctwa, tłumacząc swoim współczesnym, niechętnym uczeniu się samodzielnemu, bez podparcia się "dobrą szkołą", że wcale nie jest ono pozbawione jakiegoś kierownictwa. Chodzi tylko o to, aby osoba ucząca się mogła mieć większy wpływ na wybieranie sobie nauczycieli spoza najbliższego otoczenia, „wśród pisarzy wszystkich narodów i wieków, korzystając z istnienia książek" (Kozłowski 1902, s. 181). Jak to ujął w pytaniu, „dlaczegożby było większym wstydem uczyć się od Platonów, Kantów, Laplace’ów, Darwinów, niż od Pana X z Gimnazjum św. Anny lub od Pana Y z Wszechnicy Jagiellońskiej?” (Kozłowski 1902, s. 181). Samouctwo jako forma samokształcenia to samodzielne korzystanie $\mathrm{z}$ wiedzy bez pośrednictwa uczonego-wykładowcy, to uczenie się "otwarte", wykorzystujące każdą sytuację i okazję do zdobycia nowej wiedzy i poszerzenia już posiadanej, to - oprócz książek - kontakt z drugą osobą i otwarcie na wszystko, co może nas w niej ubogacić: słowo, sądy, przykład itd. (Kozłowski 1902, s. 41). Samoukiem dla Kozłowskiego był i powinien być każdy uczeń. Miał on „przepracowywać własnym wysiłkiem samodzielnie cały materiał szkoły. Liczyć - według niego - na wlewanie mądrości do głowy ucznia podczas lekcji, trwających po sześć godzin dziennie jest absurdem psychologicznym i pedagogicznym. Natomiast wykształcenie samego siebie powinno być przez szkołę popierane gorliwie, lecz pozostawione samodzielności czytelników" (Kozłowski 1927, s. 3).

Kozłowski jako krytyk sobie współczesnej szkoły - już z czasów niepodległej Polski - zarzucał jej wiele kardynalnych wad, jak np. przeciążenie pod pretekstem ułatwienia przez nadmierną liczbę godzin i bezmyślne programy czy wprowadzanie wiadomości, które nie są naukowymi, choć pod taką etykietą widnieją. Powoduje to według niego wzrost nietolerancji dla odmiennych poglądów, nienawiść dla ich wyznawców i brak własnego sądu. Wśród postulatów, które sam proponował dla uzdrowienia szkolnictwa, znalazły się m.in.: 1) „zniesienie wszystkich praw i przywilejów połączonych z patentem szkoły średniej, który nie powinien zawierać nic ponad stwierdzenie jej ukończenia” (czyli zniesienie matury); 2) „szerzenie oświaty $\mathrm{w}$ jak najszerszych warstwach ludu z konsekwencją nieuniknioną: usunięcie wszelkich przeszkód do wstąpienia do niej z odpowiednich klas szkoły elementarnej, a przejścia z niej do szkół wyższych wszelkiego typu”; 3) „prawodawcza ochrona dzieci przed przeciążeniem"; 4) przeniesienie w obręb zgromadzeń kościelnych zaznajomienia z zasadami wyznań, a do szkół wprowadzenie nauki etyki (Kozłowski 1927, s. 4). 
Te postulaty powiązane były z krytyką matury. W przejmującym szkicu Precz $z$ maturą!, z 1926 roku, krytykuje egzamin maturalny, wskazując, że była to metoda karania i zastraszania polskiej młodzieży w czasach zaborów, po odzyskaniu niepodległości natomiast wciąż pozostaje przestarzałym i nikomu niepotrzebnym aparatem „do gaszenia świateł w narodzie”, wspierającym biurokrację i służącym władzy do obsadzania „wszystkich stanowisk swoimi pionkami” (Kozłowski 1926, s. 12-13).

Podsumowując, można uznać, że naukę szkolną i kształcenie się samodzielne Kozłowski traktował jako dwie odrębne sprawy: nauka szkolna tworzy uczonych, kształcenie się samodzielne daje wykształcenie. Uczoność nie równa się wykształceniu. Prawdziwe wykształcenie wyróżnia się dwiema cechami: syntezą „wiadomości w całość poglądu ogólnego” oraz samodzielnym wyrobieniem tej syntezy: „zasymilowanie jej z naszą indywidualnością [...]. Pierwsza tworzy całość z fragmentarycznych informacji najrozmaitszych dziedzin; wytwarza spoistość i jednolitość podstaw, na których opieramy nasze sądy; druga czyni te sądy naprawdę naszymi. Można całe życie uczyć się, nie zdobywając wykształcenia, i można mieć gotowe sądy na wszelkie możliwe okoliczności, nie będąc autorem tych sądów" (Kozłowski 1932, s. 21). Dobrze się dzieje, jeśli szkoła wychowuje (uszlachetnia charakter, wyrabia karność i wolę) i uczy (wyrabia umysł, przyzwyczaja do myślenia systematycznego i poprawnego, ćwiczy w tym i udziela wiadomości początkowych), w ten sposób przygotowuje do wyrobienia przekonań, sama ich nie wpajając. Celem zaś kształcenia samego siebie jest „wyrobienie odpowiedzi na zagadnienia przez życie nasuwane; utworzenie przekonań, które by się stały modłą postępowania" (Kozłowski 1932, s. 23). Tu pomocną będzie książka, po którą będzie się sięgać.

\section{Co i jak czytać? - w ramach ideału wszechstronnego wykształcenia}

W odpowiedzi na pytanie zawarte w tytule tego rozdziału Kozłowski opracował podręcznik metodyczny, mający stanowić pomoc w tej samodzielnej pracy ksztalcenia samego siebie, a więc dla samouka. Książka ukazała się w 1900 roku, potem wychodziły kolejne jej wydania, ostatnie ukazało się w 1932 roku. Sądząc po liczbie wydań, miała ona sporo czytelników, wnosić można, że samouków bądź pedagogów zainteresowanych wskazywaniem dróg wykształcenia siebie.

Kształcenie siebie wyzwala z dziecięctwa rozumianego jako niesamodzielność, jest oświeceniem jednostki. Dziecięcość nie jest zawiniona, ale rezygnacja z pracy nad sobą, aby wyjść z niesamodzielności, już taką winą naznacza. „Ideałem prawdziwego wykształcenia jest dać każdemu możność mieć myśli własne, mieć swój niezapożyczony i z głębokiego przekonania płynący sąd o rzeczach w zakresie życia, sztuki, wiedzy. Zadaniem wykształcenia nie jest uczynić każdego pisarzem; ale rzec można, że każdy człowiek wykształcony jest pisarzem w możności” tymi słowy kończy Kozłowski rozdział wstępny do ostatniego wydania dzieła Co i jak czytać? (Kozłowski 1932, s. 30). Zderzmy to z cytatem z Fichtego, w którym 
zostaje uchwycona rozterka młodej osoby, która przeszła przez długi ciąg nauczania i wychowania, jakiemu podlegała i pyta: „Jaką drogą doszedłem do tych wiadomości, które [...] posiadam? Czy pędzony żądzą wiedzy przedzierałem się przez niepewność, przez wątpienie i sprzeczność? [...] Nie, nie przypominam sobie takiego stanu. Owe pouczenia zostały mi podsunięte, zanim ich zapragnąłem; odpowiadano mi, zanim zadałem pytanie. Słuchałem, ponieważ nie mogłem tego uniknąć..." (Fichte 2002, s. 17). Kozłowski interpretuje tę myśl jako uchwytujący trafnie moment, w którym można podjąć decyzję o obraniu siebie za przewodnika w życiu, czyli własne przekonanie, własny sąd o rzeczach w oparciu o dążenie do krytycznego wyrobienia tego przekonania.

Pierwszym impulsem do pisania Co i jak czytać? - przyznaje Kozłowski w Przedmowie - był przekazany mu podczas zesłania na Syberię w przesyłce z książkami katalog dzieł do czytania z różnych dziedzin, który sporządził jego młodszy brat Kazimierz. Starszy brat przyznał, że było to dla niego bardzo pożyteczne. Myśląc o napisaniu książki na ten temat, zastanawiał się jednak, czy w ogóle jest „możliwe pokierowanie czytelnictwem kształcącym bez pogwałcenia indywidualności kształcącego się” i czy możliwe jest opracowanie katalogu „dzieł wyborowych" odpowiednich dla wszystkich (Kozłowski 1932, s. 14). Po długim przemyśleniu autor zdecydował się na opracowanie książki, która byłaby zbiorem ogólnych wskazówek metodycznych, nieprzesądzających „o wynikach, do jakich lektura ma prowadzić”, wraz z wykazem tytułów dzieł, „które zdobyły sobie niezachwiane prawo do tego, by je uważać za wartościowe i kształcące”, stroniąc od narzucania poglądów, przekonań i celów. Nic bowiem nie jest bardziej sprzeczne z pojęciem wykształcenia, ,jak narzucanie gotowych, samodzielnie nie zdobytych, krytycznie nie przetrawionych i na sumiennym warzeniu nie osnutych poglądów. W taki sposób hoduje się tylko poczucie stada - gregarność; fabrykuje się ślepe narzędzia stronnictw, gotowe iść bezkrytycznie za hasłami swoich przywódców, ale nie wolne, samodzielnie myślące i stanowiące o sobie jednostki" (Kozłowski 1932, S. 15).

Z kolei przygotowując $\mathrm{w} 1925$ roku piąte wydanie popularnego i sprawdzonego w czasach niewoli wydawnictwa, autor zastanawiał się, na ile formuła dzieła może pozostać niezmieniona w czasach wolności. Przyznawał, że myślą przewodnią pierwszych wydań było oczekiwanie, że książka będzie „wychowawczynią pokoleń z lat niewoli”, rozbudzi pragnienie niepodległości i pragnienie postępu, które jest warunkiem życia narodu. W czasach niepodległej już Polski autor doszedł do wniosku, że myśl przewodnia wcale nie musi ulec zmianie, ponieważ „duch stronniczy i sekciarstwo”, „partyjniactwo” w dalszym ciągu zagrażają rozwojowi umysłu indywidualnego, dając albo gotowe rozwiązania, albo stronnicze, które „zacieśniają widnokręgi”, i zamiast bezstronnego poszukiwania prawdy, rozleniwiają myśl i wolę, przyzwyczajając do podporządkowywania się racjom walczących ze sobą ugrupowań i ich wodzirejów (Kozłowski 1932, s. 11). Tym samym samouctwo nie traciło na znaczeniu, o ile pozwalało krzewić ideał wszechstronnego wykształcenia. 


\section{Podsumowanie}

Powyższe rozważania pozwalają skonstatować, że warto postulować samouctwo jako edukację biegnącą równolegle do tej formalnej i po jej zakończeniu - np. w ramach szerszego projektu wykształcenia samego siebie. Ma to dziś sens, o ile chcemy, aby edukacja zostawiała miejsce na samodzielny wybór i nie gasiła inicjatywy sięgania po wiedzę i lektury bezinteresownie, aby nie powstawała tylko z zamówienia klientów, oczekujących od szkoły spełniania ich interesów. Po drugie, jest ono nieuniknione, jeśli myślimy o uczeniu się przez całe życie. Trzeba umieć wyjść ze szkoły i myślenia szkolnego, formatujących umysły dzieci i młodzieży, i nie pomagających w uniezależnianiu się w myśleniu. Po trzecie, można na koniec rozważać samouctwo jako formę oporu wobec szkolnictwa, ale nie w jej skrajnej postaci - deskolaryzacji.

Pochwała samouctwa - w ramach refleksji nad osobnością i uczeniem się myślenia w samotności - współgra $\mathrm{z}$ koncepcją wszechstronnego wykształcenia. Tworzy wtedy akord, w którym słychać humanizujące brzmienie edukacji non profit (Nussbaum 2016). Wskazania Kozłowskiego brzmią w mojej ocenie nad wyraz aktualnie. Był on przekonany, że trzeba uczynić wszystko na rzecz powiększenia kręgu ludzi inteligentnych, czy, mówiąc słowami Arendt, kręgu ludzi myślących. Zaliczał do niego ludzi o wszechstronnym wykształceniu. Człowiek inteligentny powinien być fachowcem w swojej specjalności ale jednocześnie powinien też lepiej niż inni rozumieć wymagania swojego czasu, a za sprawą ćwiczonej zdolności myślenia abstrakcyjnego, zdolności logicznego myślenia, być wolny od zabobonów i uprzedzeń oraz sprawniej dobierać środki do celów, formułować ideały, rozsądnie przewidywać. Jeśli się to zaniedba, absolwenci szkół będą w najlepszym razie „uczonymi rzemieślnikami”, ale nie ludźmi inteligentnymi. Z kolei wykształcenie wszechstronne nie tylko rozszerza horyzonty umysłowe i pozwala doświadczać pełni człowieczeństwa, lecz także podnosi jakość przygotowania zawodowego. Tak jak Kozłowski, choć krytykuję współczesną szkołę, nie polecam zdobywania wiedzy całkowicie poza szkołą. Ale wyprowadźmy z niej nadmiar wiedzy, a wprowadźmy do niej więcej okazji do spotkania innych oraz samych siebie, poprzez doświadczenie myślenia w samotności (w nauczaniu i uczeniu się) i dialogu (w wychowaniu).

\section{Bibliografia}

Alves A. (2019). The German Tradition of Self-Cultivation (Bildung) and its Historical Meaning. „Educação \& Realidade”, nr 2 (44), s. 1-18.

Arendt H. (2016). Życie umysłu. Buczyńska-Garewicz H., Piłat R., Baran B. (tłum.). Warszawa: Wydawnictwo Aletheia.

Arendt H. (2000). Kondycja ludzka. Łagodzka A. (tłum.). Warszawa: Fundacja Aletheia. 
Brzezińska A. (1985). Żywotność myśli psychologicznej i pedagogicznej Władysława Mieczysława Kozłowskiego. W: Myśl i życie. O humanizmie polskim Władysława M. Kozłowskiego. Andrzejewski B. (red.). Poznań: Wydawnictwo Naukowe UAM.

Fichte J.G. (2002). Powołanie człowieka. Zieleńczyk A. (tłum.). Kęty: Wydawnictwo Antyk.

Ingarden R. (1987). Ksiażeczka o człowieku. Kraków: Wydawnictwo Literackie.

Ingarden R. (1989). Wykłady z etyki. Warszawa: PWN.

Kołłątaj H. (1953). Stan oświecenia w Polsce w ostatnich latach panowania Augusta III (1750-1764). Wrocław: Ossolineum.

Kozłowski W. (1902). Z haseł umysłowości współczesnej. Kraków: Wydawnictwo Redakcyi „Poglądu na świat”.

Kozłowski W. (1921). Szkic życia Locke’a i pozostałych dzieł. W: O rozumie ludzkim. Locke J. Warszawa.

Kozłowski W. (1926). Precz z matura! Warszawa-Poznań: nakładem własnym autora.

Kozłowski W. (1927). Uzdrowienie szkoły średniej. „Życie Wolne”, nr 1(4).

Kozłowski W. (1932). Co i jak czytać? Wykształcenie samego siebie i drogi do niego. Warszawa: Gebethner and Wolff.

Locke J. (1955). Rozważania dotyczace rozumu ludzkiego. Gawecki B. (tłum.). T. 1-2. Warszawa: PWN.

Nussbaum M. (2016). Nie dla zysku. Dlaczego demokracja potrzebuje humanistów. Pawłowski Ł. (tłum.). Warszawa: Biblioteka Kultury Liberalnej.

Oakeshott M. (2001). The Voice of Liberal Learning. Indianapolis: Liberty Fund.

Oakeshott M. (1959). The Voice of Poetry in the Conversation of Mankind. London: Bowes \& Bowes.

Postman N. (1999). W stronę XVIII stulecia. Jak przeszłość może doskonalić nasza przyszłość. Frąc R. (tłum.). Warszawa: Państwowy Instytut Wydawniczy.

Tischner J. (2000). Etyka solidarności. Kraków: Wydawnictwo „Znak”.

Tischner J. (2002). Myślenie według wartości. Kraków: Wydawnictwo „Znak”.

Tischner J. (2008). Spotkanie. Rozmowa Anny Karoń-Ostrowskiej z ks. Józefem Tischnerem. Kraków: Wydawnictwo „Znak”.

deWitt P. (2019). Smartfony odebrały nam samotność. Wywiad z Natalia Szostak, dostępny na: http://www.wysokieobcasy.pl/wysokie-obcasy/7,127763,24366252, smartfony-odebraly-nam-samotnosc.html (dostęp 9.05.2020).

Wrońska K. (2020). Samouctwo - w myśli pedagogicznej i życiu Władysława M. Kozłowskiego. W: Wielogłos w myśli o wychowaniu. 100 lat polskiej pedagogiki filozoficznej. Sztobryn S., Dworakowska K. (red.). Warszawa: Wydawnictwo Uniwersytetu Warszawskiego.

Wrońska K. (2015). Uwagi o recepcji twórczości pedagogicznej Johna Locke’a w Polsce $z$ perspektywy pedagogiki filozoficznej. W: Filozofia wychowania w Europie Środkowej w kontekście uwarunkowań historycznych, społecznych, politycznych 
i filozoficznych. Sztobryn S., Kamiński K., Wasilewski M. (red.). Łódź: WN TPF "Chowanna".

Wrońska K. (2018). Wychowanie a wolność. Próba wgladu w myślenie pedagogiczne Józefa Tischnera. „Paedagogia Christiana”, nr 1 (41), s. 97-115.

Wrońska K. (2012). Pedagogika klasycznego liberalizmu w dwugłosie John Locke i John Stuart Mill. Kraków: Wydawnictwo UJ.

\title{
THE PRAISE OF SELF-INSTRUCTION IN THE CONTEXT OF ALONENESS AND SOLITUDE - AGAINST THE CONTEXT OF WŁADYSŁAW M. KOZŁOWSKI'S CONCEPT OF SELF-EDUCATION
}

\begin{abstract}
The author considers the present sense and meaning of self-instruction - in connection to the issue of being alone and solitary - against the context of one of historical concepts of self-education in Poland. Aloneness as a mode of human existence, of a thinking being, is a philosophical starting point of our analysis. It is assumed that education has an important role to play in learning to think, which, however, requires being alone (at home with oneself). Therefore, the author proposes to recall one of the concepts of self-instruction developed in Poland during the partitions and interwar period, as an example of experiencing oneself and learning to think in solitude; not outside of education but within it. The hermeneutic analysis and interpretation of the problem allows to demonstrate the validity of self-instruction as a necessary humanizing complement to school education in Poland, balancing between the extremes of encyclopaedism and instrumentalism. Finally, it allows gathering several arguments for education beyond professionalization and education that promotes the human condition as vita activa.
\end{abstract}

Keywords: self-instruction; solitude; aloneness; thinking; self-education; education. 